\title{
Activitate educațională ultrasonografică online intensă în era covid
}

Pe lângă multe alte efecte negative asupra vieții economice și sociale, pandemia COVID a avut repercursiuni și asupra învățământului medical românesc în general și asupra celui ultrasonografic în special. Cursurile de formare în ultrasonografie, cu valențele practice deosebite ale acestora (sesiuni hands-on pe pacient) nu s-au mai putut organiza în varianta on-site. Cursurile s-au ținut online iar activitatea practică s-a condensat în week-end-uri fiind practicată pe modele.

Câștigarea experienței online prin implementarea diverselor platforme (TEAMS, ZOOM, etc) în activitatea didactică școlară și universitară precum și succesul primei conferințe naționale de ultrasonografie desfășurată online au făcut ca în anul 2020 să asistăm la o activitate educațională online intensă ultrasonografică.

Una din activitățile de vârf organizate în domeniul ultrasonografiei a fost cea prin proiectul EduSon. EduSon Medical este o platformă online de învățare la distanță, dedicată ultrasonografiei, care își propune să vină atât în întâmpinarea medicilor debutanți în tehnica ultrasonografică, cât și în ajutorul specialiștilor care doresc să își îmbunătățească această tehnică de explorare imagistică, cu un conținut de calitate, asigurat prin prisma experienței lectorilor și coordonatorilor acestui proiect. Prezentările sunt susținute în format tip webinar, îmbinând partea teoretică cu aplicațiile practice și cazuistică de specialitate, participanții putând interacționa cu lectorii prin intermediul platformei.

Până în prezent au fost organizate numeroase webinarii pe platforma FLYINSONO (https://eduson.numeris.ro/webinar/). Primele 4 module au avut ca și scop introducerea în tehnicile de examinare ultrasonografică precum și familiarizarea cu particularitățile examinării diferitor regiuni anatomice. Următoarele webinarii organizate în a doua parte a anului 2020 precum și în primele luni din 2021 (ȘCOALA DE VARĂ Actualități în Ultrasonografie, NefroUroSon - "Ultrasonografia în Nefrologie și Urologie”, SonoVasc - "Ultrasonografia Vasculară periferică și viscerală”, SonoHep - "Ultrasonografia în Hepatologie. Hepatopatii Difuze”) au fost urmărite de un număr mare de participanti și au beneficiat de aportul unor ecografiști cu bogată experiență. Desfășurarea proiectului EduSon a permis creionarea avantajelor învățării continue ultrasonografice în mediul online: a) accesibilitate (confort, flexibilitate); centrare pe nevoile grupului țintă; existenta conținuturilor multimedia (care pot fi corectate și complete mereu); b) învățare sincron - prin simularea situațiilor din practică si încurajarea învățării în grup (discuții la caz); c) acces la cazuistică variată; d) acces la expertiza unor profesioniști în domeniu (posibilitate de adresare întrebări și obținere a unui răspuns prompt). Avantajele dovedite ale educației

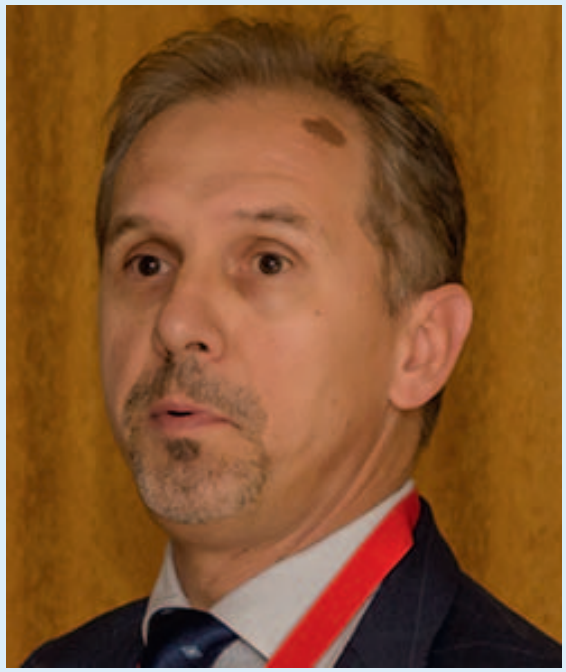

Prof. Dr. Spârchez Zeno

ultrasonografice online o recomandă ca o formă care poate fi continuată și după trecerea pandemiei.

În încheiere trebuie să subliniem că activități educaționale ultrasonografice online au fost organizate și de celelalte centre de formare în ultrasonografie.

\section{Prof. Dr. Spârchez Zeno}

Președinte ales SRUMB 2022-2024

\section{Prof. Dr. Badea Radu}

Membru în Comitetul Director al SRUMB 